\title{
A Case Report of 1p36 Deletion Syndrome and Suspected Cytomegalovirus Infection
}

\section{1p36 Delesyon Sendromuna Eşlik Eden Şüpheli Konjenital Sitomegalovirüs Enfeksiyonlu Vaka Sunumu}

Oguz Egil ${ }^{1}$,

Sevgi Pekcan ${ }^{1}$

Esra Hazar Sayar ${ }^{1}$

Sukru Nail Güner ${ }^{1}$

Mahmut Selman Yildirim²

${ }^{1}$ Necmettin Erbakan University, Meram Faculty of Medicine, Department of Pediatrics, Konya, Turkey

${ }^{2}$ Necmettin Erbakan University, Meram

Faculty of Medicine, Department of Genetics, Konya, Turkey

Geliş Tarihi/Received: 29 Marc 2018

Kabul Tarihi/Accepted: 04 June 2018

Address correspondence to: Oguz Egil, Necmettin Erbakan University, Meram Faculty of Medicine, Department of Pediatrics, Konya e-mail: eoguzegil@hotmail.com

ORCID

Oguz Egil

https://orcid.org/0000-0001-5112-5733

\begin{abstract}
Öz
1p36 Delesyon Sendromu 1. kromozomun kısa kolundaki parsiyel delesyon ile karakterize, nadir görülen bir konjenital malformasyon sendromudur. Illk vakalar Hain ve arkadaşları ile başlayarak 1980'lerin başında yayınlanmıştır. 1987'de Magenis ve arkadaşları ilk saf vakayı tarif etmiştir. Hastalığın görülme insidansı 1/5000-1/10000 olup, kadın-erkek oranı ise 2/1'dir. Karakteristik bulguları tipik yüz görünümü, gelişme geriliği, beslenme sorunları, santral sinir sistemi anomalileri, epilepsi, mikrosefali, görme problemleri, işitme kaybı, konjenital kalp defektleri, böbrek ve iskelet anomalileridir. Konjenital Sitomegalovirüs enfeksiyonunu ise spesifik bir tedavisi bulunmayan fetüs üzerinde kalıcı etkileri bulunan bir intrauterin hastalıktır. Sitomegalovirüs enfeksiyonunun yaygın klinik bulguları peteşi, doğumda sarılık, hepatosplenomegali, mikrosefali, hipotoni, beslenme güçlüğü, sensorinöral işitme kaybı, görme anormallikleri, epilepsi, gelişimsel serebral anomaliler, intrauterin gelişme geriliği, prematürite ve ölü doğumdur. Bu olgu, 1p36 Delesyon Sendromu gibi nadir görülen bir hastalığa ve ilk kez 7 aylıkken CMVDNA pozitifliği saptanan konjenital Sitomegalovirüs enfeksiyonuna benzer bir kliniğe sahip nadir bir örnek olması nedeniyle bildirilmiştir.
\end{abstract}

Anahtar Kelimeler: 1p36 delesyon sendromu, konjenital CMV enfeksiyonu, intrauterin enfeksiyon

\section{Abstract}

1 p36 Deletion Syndrome is a rare disease characterized by a partial deletion in the short arm of chromosome 1. The first reports of cases with microdeletion of chromosome 1 p36 were published in 1980 s, beginning with a report by Hain et al. The first pure case of 1 p36 Deletion Syndrome was identified in the 1987 by Magenis et al. Its incidence is presumed as 1:5000 to 1:10000 and prevalence among men/women is $1 / 2$. Characteristic signs are dysmorphic facial features, developmental delay, feeding difficulties, central nervous system anomalies, seizures, microcephaly, intellectual disability, vision problems, sensorineural deafness, congenital heart defects, skeletal and renal anomalies. Congenital Cytomegalovirus infection is an intrauterine disease with persistent effects on the fetus with no specific treatment. Common clinical findings are petechiae, jaundice at birth, hepatosplenomegaly, microcephaly, hypotonia, poor suck, sensorineural hearing loss, vision abnormalities, seizures, developmental cerebral anomalies, intrauterine development delay, prematurity and stillbirth. This case is reported due to being a rare sample having such a rare disease such as 1 p36 Deletion Syndrome and a corresponding clinical picture to congenital Cytomegalovirus infection which she was firstly determined with a positive CMV-DNA level when she was 7 months old.

Keywords: 1 p36 deletion syndrome, congenital CMV infection, intrauterine infection

\section{INTRODUCTION}

$1 \mathrm{p} 36$ Deletion (1p36D) Syndrome is a rare disease characterized by a partial deletion in the short arm of chromosome 1. The very first cases were published in the early 1980s, starting with Hain et al. (1). Since there were other simultaneous unstable translocations in these cases, it was difficult to determine which effect is due to the deletion of chromosome 1. Magenis et al. described the first pure case in 1987. (2). Its incidence is presumed as $1: 5000$ to $1: 10000$ and prevalence among men/women is $1 / 2$. (3). $1 \mathrm{p} 36$ Deletion (1p36D) Syndrome is a rare disease characterized by a partial deletion in the short arm of chromosome 1 . Its incidence is presumed as 1:5000 to 1:10000 and prevalence among men/women is $1 / 2$. Characteristic signs are dysmorphic facial features, developmental delay, feeding difficulties, developmental cerebral anomalies, seizures, microcephaly, vision problems, sensorineural deafness, congenital heart defects and renal and skeletal anomalies. (4).

Congenital Cytomegalovirus (CMV) infection is an intrauterine disease with irreversible effects on the fetus with no specific treatment. Common clinical findings of CMV infection are petechiae,
Cite this article as: Egil O, Pekcan S, Sayar EH, Guner SN, Yildirim MS. A Case Report of 1 p36 Deletion Syndrome and Suspected Cytomegalovirus Infection. Selcuk Med J 2019;35(1): 63-68
Disclosure: Yazarların hiçbiri, bu makalede bahsedilen herhangi bir ürün, aygut veya ilac ile ilgili maddi sıkar ilişkisine sahip değildir Araştırma, herhangi bir dis organizasyon tarafından desteklenmedi Yazarlar calışmanı birincil verilerine tam erişim izni vermek ve derginin talep ettiği takdirde verileri incelemesine izin vermeyi kabul etmektedirler. 
jaundice at birth, hepatosplenomegaly, microcephaly, hypotonia, poor suck, sensorineural hearing loss, vision abnormalities, seizures, developmental cerebral anomalies, intrauterine development delay, prematurity and stillbirth. (5).

\section{CASE}

7 months old girl has been consulted to pediatric pulmonology unit because of feeding difficulties, failure to thrive and respiratory problems. Her parents were not related and she had no sibling although her mother had two miscarriages. She was born mature but small for gestational age (SGA), $2400 \mathrm{~g}$. she was intubated because of respiratory problems for 1 day. She had a mild jaundice at birth and took phototherapy.

In her physical examination, her weight was $4400 \mathrm{~g}$ $(<3 p)$, height was $62 \mathrm{~cm}(3-10 p)$, head circumference was $37.5 \mathrm{~cm}(<3 p)$. Her respiratory rate was 48/ minute, oxygen saturation was $82 \%$, temperature was $36.9^{\circ} \mathrm{C}$, heart rate was 118 pulse/minute and blood pressure was $80 / 40 \mathrm{mmHg}$. She was hypotonic, she couldn't keep her head up and couldn't sit whether with or without support. She could not speak but recognize her mother. She had some dysmorphic facial features such as asymmetric face, straight eyebrows, deep set eyes, epicanthal folds more significant in her left eye, short narrow and slanting palpebral fissures, midface retrusion, long philtrum, pointed chin and small mouth with down-turned corners. Her anterior fontanel was

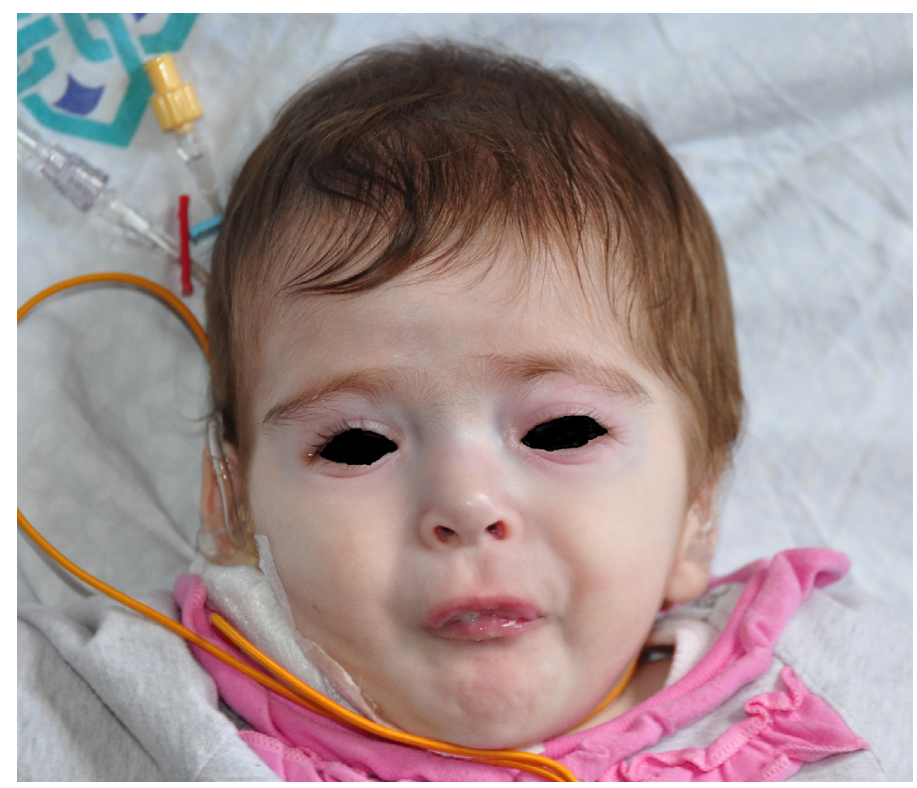

Figure 1. Facial appearance of case 10x5 mm and still open. (Figure 1)

Patient was firstly consulted to pediatric neurology with resistant seizures when she was 2 months old. Her electroencephalography (EEG) was performed while sleeping; resulting 5-6 theta rhythms in background and intermittent pointed wave paroxysm especially in right hemisphere. Results were matching with multiform epilepsy. Bilateral congenital cataract was determined when she was 3 months old. It is said that she was performed a cataract operation and she would be examined to get another one to replace her lenses or not, when she is above 2 years old. At the same time, her hearing loss was revealed. She had no problem when she had performed newborn otoacoustic emission measurement test. She was using contact lenses for cataract and hearing devices for hearing loss when we firstly examined her.

Patient hospitalized to pediatric pulmonology for further evaluation. Esophageal $\mathrm{pH}$ testing was performed: Reflux index was 2.1 reflux/hour, total period in reflux were 1 hour 50 minutes $(7.5 \%$ of total testing time), the longest reflux period was 15.4 minutes and number of long reflux period was 4 . Case was diagnosed as gastro-esophageal reflux disease (GERD). A control echocardiography resulted as mild tricuspid insufficiency. Other laboratory tests such as hemogram, biochemical analysis including kidney and liver function tests and thyroid hormones were normal. White blood cells: $15600 / \mathrm{mm} 3$, neutrophile: 11900/mm3 (\%76) lymphocytes: 3200/mm3 (\%20), platelets: $348000 / \mathrm{mm} 3$, hemoglobin: $11,0 \mathrm{~g} / \mathrm{dL}$, CRP was $39,3 \mathrm{mg} / \mathrm{L}$. Computerized cranial tomography, spinal graphy and pelvic ultrasonography was also performed and no pathologic outcome was confirmed. Chromosomal microarray test was performed by consulting pediatric neurology and genetics. The results were: " $6922 \mathrm{~kb}$ sized deletion between $1 \mathrm{p} 36.33$ and $1 \mathrm{p} 36.23$ areas. Deletion areas involve 72 OMIM genes including MMP23B, GABRD, KCNAB2, SKI and PRDM16." Case has been admitted as "1p36D Syndrome" in consequence of current clinic and laboratory analysis. Supporting symptoms and signs were dysmorphic facial features, feeding difficulties, growth retardation, seizures, bilateral cataract, hearing loss, tricuspid insufficiency and GERD. (Table 1)

Bronchoscopy was practiced due to the increase of oxygen need, doubt of laryngomalacia/ bronchomalacia and findings of consolidation on right lung in posteroanterior chest radiography and "focal consolidation and subsegmental atelectasis in 
Table 1. Comparison between prevalence of signs of 1P36D Syndrome and our case

\begin{tabular}{lll}
\hline 1P36D Syndrome Symptoms and Signs & Our Case & Prevalence \\
\hline Typical facial features: & & $75 \%$ \\
Microbrachycephaly & $(-)$ & $61-65 \%$ \\
Late-closing anterior fontanel & $?$ & $77 \%$ \\
Straight eyebrows & $(+)$ & $77 \%$ \\
Epicanthal folds & $(+)$ & $50 \%$ \\
Short narrow and slanting palpebral fissures & $(+)$ & $26 \%$ \\
Deep set eyes & $(-)$ & $73-100 \%$ \\
Midface retrusion & $(+)$ & $51-100 \%$ \\
Posteriorly rotated low set abnormal ears & $(-)$ & $40-49 \%$ \\
Wide and depressed nasal bridge & $(-)$ & $65 \%$ \\
Small mouth with down-turned corners & $(+)$ & $\mathrm{N} / \mathrm{A}$ \\
Pointed chin & $(+)$ & $43-100 \%$ \\
Developmental delay & $(+)$ & $100 \%$ \\
Hypotony & $(+)$ & $95 \%$ \\
Hypothyroidism & $(-)$ & $15-20 \%$ \\
Developmental cerebral anomalies & $(-)$ & $88 \%$ \\
Seizures & $(+)$ & $44-58 \%$ \\
Congenital heart defects & $(+)$ & $43-71 \%$ \\
Vision problems & $(+)$ & $40-64 \%$ \\
Sensorineural deafness & $(+)$ & $47-82 \%$ \\
Skeletal anomalies & $(-)$ & $41 \%$ \\
External genitalia abnormities & $(-)$ & $22 \%$ \\
Renal anomalies & $(-)$ & $22 \%$ \\
\hline
\end{tabular}

posterior of upper lobe apex of right lung" in thorax computerized tomography. In the bronchoscopy, omega epiglottis, secretion and malacia in the entrance of right main bronchus has been seen. E. coli reproduced in bronchoalveolar lavage (BAL) fluid. Pathology report of BAL was: "scarce columnar and squamous epithelial cells among numerous neutrophiles and polimorphonuclear cells in preparates stained with hemotoxylin-eosine and pap dye." It was interpreted as omega epiglottis and a possible lung infection sequel. Because of her similar clinical picture, CMV-DNA level (PCR) was also performed from BAL and resulted as 317.000 copies. CMV-DNA level of blood was 251 copies and CMV-DNA level of urine was 521.000 copies, too. Her mother's current CMV-DNA level was negative, CMV lg-M was negative and Ig-G was positive.

She had a similar clinical picture with congenital CMV infection such as growth retardation, seizures, bilateral cataract, hearing loss and significant laboratory findings (Table 2). Not being to able to exclude congenital CMV infection, appropriate

Table 2. Comparison between prevalence of signs of Congenital CMV Infection and our case

\begin{tabular}{lll}
\hline Congenital CMV Infection Symptoms and Signs & Our Case & Prevalence \\
\hline Petechiae & $(-)$ & $54-76 \%$ \\
Jaundice at birth & $(+)$ & $38-67 \%$ \\
Hepatosplenomegaly & $(-)$ & $39-60 \%$ \\
Microcephaly & $(+)$ & $36-53 \%$ \\
Small size for gestational age & $(+)$ & $39-50 \%$ \\
Sensorineural deafness & $(+)$ & $34 \%$ \\
Hypotonia & $(+)$ & $27 \%$ \\
Poor suck & $(+)$ & $19 \%$ \\
Vision problems & $(+)$ & $11-14 \%$ \\
Seizures & $(+)$ & $4-11 \%$ \\
Hemolytic anemia & $(-)$ & $11 \%$ \\
Pneumonia & $(+)$ & $8 \%$ \\
Development delay & $(+)$ & $\mathrm{N} / \mathrm{A}$ \\
Elevated liver transaminases & $(-)$ & $50-83 \%$ \\
Thrombocytopenia & $(-)$ & $48-77 \%$ \\
Elevated direct and indirect serum bilirubin & $(-)$ & $36-69 \%$ \\
Intracranial calcifications, usually periventricular & $(-)$ & $34-70 \%$ \\
\hline
\end{tabular}


antibiotherapy and 6 months Ganciclovir treatment (5 $\mathrm{mg} / \mathrm{kg} /$ day) were planned. She had a good response to Ganciclovir and she gained some weight. Her oxygen need and hypotonicity has decreased. Her interest to environment has increased and she started to sit with support. So, we decided to continue to the treatment.

\section{DISCUSSION}

1 p36 Deletion (1p36D) Syndrome is a rare disease characterized by a partial deletion in the short arm of chromosome 1. Its incidence is presumed as 1:5000 to $1: 10000$ and prevalence among men/women is $1 / 2$ (3). Its signs and symptoms are summarized in table $1(4,6,7)$. Vomiting, feeding difficulties and GERD are seen frequently in infants (8). Our case also had that. Like our case, Seizures are seen in 44 to $58 \%$ of the cases in literature. Hipsarrhytmias with infantile spasm is often reported. Developmental cerebral anomalies are seen in $88 \%$ of patients. Most common anomalies are corpus callosum anomalies, diffuse cerebral atrophy, insufficient myelinization and periventricular nodular heterotopy (3).

Vision problems are identified in 40 to $64 \%$ of patients in literature. Most frequently seen anomalies are refractive errors, cataract, strabismus, nystagmus, sixth nerve palsy and lacrimal defects (4). In this case, there was only bilateral cataract; she was too young to evaluate refractive errors. According to literature, 47 to $82 \%$ of the patient has hearing loss like ours (3). Congenital heart defects exist $43-58 \%$ of patients. Most frequently reported abnormities are (respectively) atrial and ventricular septal defects, valvular anomalies, patent ductus arteriousus, tetralogy of Fallot, coarctation of the aorta, infundibular stenosis of the right ventricle and Ebstein anomaly (7). Our case had only mild tricuspid insufficiency. Skeletal anomalies are also may be seen (41\%). Delayed bone age, scoliosis and rib anomalies are most common examples (3). Even if there is no sign at the moment, our patient must be followed closely in case of skeletal anomalies like every patient having early diagnosis.

To analyze our case's certain mutations; the matrix metallopeptidase 23B gene (MMP23B) is in a region causing large, late-closing anterior fontanel. A metallopeptidase is being encoded that is fundamental for bone remodeling (9). Gajecka et al, claimed that deletions of MMP23B gene induces large, late-closing anterior fontanels while duplications induces craniosynostosis (10). Gammaaminobutyric acid A receptor, delta (GABRD) gene's monosomy is thought to be related to neurodevelopmental anomalies, seizures and psychiatric disorders (11). A sidekick protein that regulates the features of functional potassium voltage-gated alpha subunits is encoded from potassium channel, voltage-gated subfamily A regulatory beta subunit 2 gene (KCNAB2). It is considered that monosomy of KCNAB2 gene contributes mental disorders, growth retardation and seizures (12). Our case has consulted for growth retardation and seizures, too.

The SKI proto-oncogene encodes a transcriptional coregulator protein whose monosomy may also assists mental disorders, growth retardation, seizures; and additionally midline abnormities and congenital heart defects which is related to terminal 1p36 microdeletions (13). A zinc finger transcription factor is encoded from the PR domain involving 16 genes (PRDM16). Monosomy of PRDM16 may result left ventricular insufficiency and cardiomyopathy. It may be also associated to myelodysplastic syndrome and acute myeloid leukemia (14). PRDM16 and SKI are associated to inhibit transforming growth factor $\beta$ signaling. PRDM16 and SKI induce a synergic effect on each other to reduce cardiac output, separately and together in zebra fish (Danio rerio) $(8,15)$.

Congenital CMV infection may be seen 1 to $2.4 \%$ of seronegative mothers. The risk of congenital CMV infection of these neonates is $40 \%$ and $10 \%$ of them are symptomatic shortly after the birth. (15). To get caught to CMV is not completely protective. Even if mother candidates get primary infection before pregnancy, they may have reactive infections or be infected again by a new strain of CMV (16). Common clinical findings are summarized in table 2. Gold standard diagnostic test is generating CMV in cell cultures from newborn's blood within 2 weeks after birth. Level of CMV Ig-M is not recommended due not to have enough sensibility and specificity (17, 18). But after three weeks to one year, CMV-PCR in urine and/or saliva or CMV Ig-G level in blood may be used for diagnosis (17). This may be called "possible" congenital CMV infection (because final diagnosis is impossible in that stage); so does our patient.

Mortality of children with symptomatic congenital CMV infection is 6 to $12 \%$ within the first week after birth. This rate may raise to $30 \%$ at the end of first year (19). Most common mortality reasons are respiratory insufficiency, bleeding disorders, fulminant liver failure and secondary bacterial infections respectively (20).

Central nervous system signs are determined in 5 to $10 \%$ of patients such as microcephaly, encephalitis, 
seizures, mental and motor retardation (21). 11-14\% of patients have vision problems like chorioretinitis and cataract (22). Our patient also had growth retardation, seizures, hypotony and cataract. Sensorineural hearing loss develops in 10 to $15 \%$ of asymptomatic neonates. In neonatal screening tests, hearing loss may not be determined because more than $50 \%$ of patients have late onset. Likewise, our patient had bilateral hearing loss and couldn't be detected while neonatal hearing screening tests. Therefore, patients should be followed for a long period of time in case of hearing loss. Mental retardation, autism, attention deficit and hyperactivity disorder and behavior disorders may be also seen so it would be better to follow them until at least school age or longer (21).

Studies have shown up that Ganciclovir treatment may stop progress of hearing loss (23). So we also started Ganciclovir treatment in our case. In our case, $1 \mathrm{p} 36 \mathrm{D}$ Syndrome seemed to be main responsible from clinical picture but "possible" congenital CMV infection was also likely similar to her manifestation. The case was already 7 months old when firstly consulted. Laboratory results while referral was compatible with CMV infection and yet she had a positive response to Ganciclovir treatment. As a consequence, we think 1p36D Syndrome as a primary disorder and CMV infection as a contributor to her clinical manifestation. It is also reported that CMV infection in intrauterine life may cause chromosome 1 breaks such as 1 p36 deletion by Fortunato et al (24). She had a partially positive response to Ganciclovir treatment so we thought that a possible congenital CMV infection in early intrauterine life might cause a 1 p36 microdeletion in our case, too.

Conflict of interest: Authors declare that there is no conflict of interest between the authors of the article.

Financial conflict of interest: Authors declare that they did not receive any financial support in this study.

Address correspondence to: Oguz Egil, Yunus Emre Mh. Necmettin Erbakan University, Meram Medical Faculty, Child Health and Diseases Secretariat, Meram/Konya 42080 Turkey. E-mail: oguzegil@hotmail.com Telephone: +90 5388722864 Fax number: +90332 2237393

\section{REFERENCES}

1. Hain D, Leversha M, Campbell N, et al. The ascertainment and implications of an unbalanced translocation in the neonate. Familial 1:15 translocation. Aust Paediatr J 1980;16(3):196200.

2. Magenis RE, Shehy R, Lacey $D$, et al. Small terminal deletion of chromosome 1 short arm in an infant with multiple anomalies: Confirmation by in situ hyridization of rove $\mathrm{p} 179$. Am J Hum Genet 1987;41:A130.

3. Battaglia A, Hoyme HE, Dallapiccola B, et al. Further delineation of deletion 1p36 syndrome in 60 patients: A recognizable phenotype and common cause of developmental delay and mental retardation. Pediatrics 2008;121(2):40410.

4. Battaglia A. Del 1p36 syndrome: A newly emerging clinical entity. Brain Dev 2005;27(5):358-61.

5. Ahlfors K, Ivarsson SA, Harris S. Report on a long-term study of maternal and congenital cytomegalovirus infection in Sweden. Review of prospective studies available in the literature. Scand J Infect Dis 1999;31:443-57.

6. Heilstedt HA, Burgess DL, Anderson AE, et al. Loss of the potassium channel beta-subunit gene, KCNAB2, is associated with epilepsy in patients with 1 p36 deletion syndrome. Epilepsia 2001;42(9):1103-11.

7. Haimi M, lancu TC, Shaffer LG, et al. Severe iysosomal storage disease of liver in del(1)(p36): A new presentation. Eur J Med Genet 2011;54:209-13.

8. Neal J, Apse K, Sahin M, et al. Deletion of chromosome 1p36 is associated with periventricular nodular heterotopia. Am J Med Genet A 2006;140(15):1692-5.

9. Jordan VK, Zaveri HP, Scott DA. 1p36 deletion syndrome: An update. Appl Clin Genet 2015;8:189-200.

10. Gajecka M, Yu W, Ballif BC, et al. Delineation of mechanisms and regions of dosage imbalance in complex rearrangements of 1 p36 leads to a putative gene for regulation of cranial suture closure. Eur J Hum Genet 2005;13(2):139-49.

11. Windpassinger $\mathrm{C}$, Kroisel PM, Wagner $\mathrm{K}$, et al. The human gammaaminobutyric acid a receptor delta (GABRD) gene: Molecular characterisation and tissuespecific expression. Gene 2002;292 (1-2):25-31.

12. Perkowski JJ, Murphy GG. Deletion of the mouse homolog of KCNAB2, a gene linked to monosomy $1 \mathrm{p} 36$, results in associative memory impairments and amygdala hyperexcitability. J Neurosci 2011;31(1):46-54.

13. Shprintzen RJ, Goldberg RB. Dysmorphic facies, omphalocele, laryngeal and pharyngeal hypoplasia, spinal anomalies, and learning disabilities in a new dominant malformation syndrome. Birth Defects Orig Artic Ser 1979;15(5B):347-53

14. https://www.ncbi.nlm.nih.gov/gene/63976

15. Arndt AK, Schafer S, Drenckhahn JD, et al. Fine mapping of the 1 p36 deletion syndrome identifies mutation of PRDM16 as a cause of cardiomyopathy. Am J Hum Genet 2013;93(1):6777.

16. Tezer $H$, Seçmeer $G$. Sitomegalovirüs (CMV) enfeksiyonları (Derleme). Hacettepe Tıp Dergisi 2007; 38:1-7.

17. Boppana SB, Ross SA, Fowler KB. Congenital cytomegalovirus infection: Clinical outcome. Clin Infect Dis. 2013;57 Suppl 4:S178.

18. Dalgıç N. Konjenital sitomegalovirüs enfeksiyonu (Derleme). Uludağ Üniversitesi Tıp Fakültesi Dergisi 2007;33(1)33-9.

19. Hanshaw JB. Congenital cytomegalovirus infection: A fifteen year perspective. J Infect Dis 1971:123:555-61.

20. Jones CA. Congenital cytomegalovirus infection. Curr Probl Pediatr Adolesc Health Care 200;33:70-93.

21. Boppana SB, Pass RF, Britt WJ, et al. Symptomatic congenital cytomegalovirus infection: Neonatal morbidity and mortality. Pediatr Infect Dis J 1992;11:93-9.

22. Çelikel E, Tezer H, Kanik-Yuksek S, et al. Evaluation of 98 
immunocompetent children with cytomegalovirus infection: Importance of neurodevelopmental follow-up. Eur J Pediatr 2015;174(8):1101-7.

23. Michaels MG, Greenberg DP, Sabo DL, et al. Treatment of children with congenital cytomegalovirus infection with ganciclovir. Pediatr Infect Dis J 2003; 22:504-8.
24. Fortunato EA, Dell'Aquila ML, Spector DH. Specific chromosome 1 breaks induced by human cytomegalovirus. Proc Natl Acad Sci U S A 2000;97(2):853-8. 